\title{
KONSUMSI INTERNET OLEH MAHASISWA STAIN GAJAH PUTIH TAKENGON DAN IMPLIKASINYA TERHADAP PEMBELAJARAN
}

\author{
Rahmanita Zakaria \\ STAIN Gajah Putih Takengon \\ Email: zrahmanita@gmail.com
}

\begin{abstract}
Abstrak: Penelitian ini merupakan penelitian yang mengidentifikasi konsumsi internet oleh para mahasiswa dan implikasinya terhadap penggunaan teknologi dalam pembelajaran. Penelitian ini dilakukan untuk mengetahui kebiasaan mahasiswa dalam menggunakan internet dengan cara pengumpulan data melalui quisioner yang dibuat untuk mengetahui interaksi mereka terhadap teknologi dan tingkat keseringan penggunaan digital dalam keseharian para mahasiswa dalam era digital saat ini. Dari hasil penelitian yang dilakukan dapat disimpulkan bahwa konsumsi internet yang dilakukan oleh mahasiswa STAIN Gajah Putih Takengon sangat aktif, mahasiswa menggunakan internet sebagai alat komunikasi, jaringan sosial, mencari informasi, penggunaan multimedia, juga sebagai alat untuk mencari hiburan dan permainan lainnya. Hampir keseluruhan dari mereka adalah pengguna internet dalam skala yang besar untuk kebutuhan menikmati permainan dan hiburan yang ada dalam era digital sekarang ini. Mereka selalu menggunakan instan pesan sebagai sarana hiburan dan hampir rata-rata selalu online dalam durasi 24 jam. Untuk itu dosen sebaiknya lebih aktif melakukan proses belajar mengajar dengan menggunakan jaringan internet, sehingga mahasiswa dengan sendirinya akan mengkonsumsi internet sebagai sarana dalam proses belajar mengajar.
\end{abstract}

Kata Kunci: Konsumsi, Internet, Implikiasi

\section{Pendahuluan}

Penelitian ini merupakan penelitian yang mengidentifikasi konsumsi internet oleh para mahasiswa dan implikasinya terhadap penggunaan teknologi dalam pembelajaran. Penelitian ini dilakukan terhadap mahasiswa STAIN Gajah Putih Takengon. Banyak dari para mahasiswa merupakan generasi online atau pemakai digital alami yang diharapkan mampu menjadi ahli teknologi dan generasi online. Penelitian ini dilakukan untuk mengetahui kebiasaan mahasiswa dalam menggunakan internet dengan cara pengumpulan data melalui quisioner yang dibuat untuk mengetahui interaksi mereka terhadap teknologi dan tingkat keseringan penggunaan digital dalam keseharian para mahasiswa dalam era digital saat ini. Prensky menyatakan bahwa banyak mahasiswa pada saat ini yang dikenal sebagai pemakai digital alami atau generasi internet (Prensky, 2018). Para mahasiswa menghabiskan hari-hari mereka dengan bermain internet, menggunakan komputer, menjelejahi web, berkomunikasi melalui telepon seluler dan bekerja dengan menggunakan internet untuk pembelajaran.

Berdasarkan hasil penelitian di Australia dan Amerika terhadap penggunaan kemajuan tehnologi dalam dunia pendidikan berimbas semakin baiknya kwalitas pendidikan disana, hal ini dapat mendorong tenaga pengajar supaya dengan kebiasaan para mahasiswa yang ada di STAIN Gajah Putih Takengon dalam penerimaan terhadap inovasi teknologi yang berkembang pesat saat ini, sehingga diusulkan kepada para dosen agar mengadopsi fasilitas-fasilitas yang terdapat dalam teknologi saat ini untuk menarik 
minat mahasiswa dan menjadikan pembelajaran lebih efektif. Hal ini senada dengan apa yang dikatakan oleh Sharon, komputer dan multimedia dapat diintegrasikan kedalam kegiatan pembelajaran (Smaldino, et al, 2011).

Dalam menciptakan iklim pembelajaran yang menarik, guru memainkan peran yang sangat besar agar pengetahuan dan keahlian yang disalurkan kepada para mahasiswa dapat diterima dan mereka mampu menyerap, menikmati dan menerapkan apa yang mereka peroleh baik secara akademik, individu maupun professional (Lever, 2003). Oleh karena itu tenaga pengajar harus mampu menyesuaikan metode dan pendekatan pembelajaran dengan lingkungan serta perkembangan teknologi yang dapat digunakan sebagai media untuk mempermudah proses pengajaran dan pembelajaran juga dengan keahlian, pengalaman dan harapan para mahasiswa. Peneliti dalam penelitian ini tertarik untuk mengkaji masalah ini atas hasil penelitian yang dilakukan oleh Kenedy et al, terhadap mahasiswa yang ada di Australia, yang temuan penelitiannya menunjukkan bahwa tidak dapat dihindari para generasi internet sering menggunakan aplikasi yang ada didalam teknologi seperti internet, email, komunikasi melalui telepon seluler, dan sistem pesan singkat (YM), Facebook, BBM, LINE, Instagram, Whatsup dan aplikasi lainnya tetapi mereka tidak menggutamakan teknologi terbaru seperti blog, wiki dan sosial bookmarking yang merupakan inovasi terbaru dalam pembelajaran.

Pengguna internet khususnya mahasiswa tidak akan mengalami kesulitan dalam menerima teknologi baru, oleh karena itu penelitian ini bertujuan untuk mengidentifikasi kebiasaan mahasiswa calon sarjana yang ada di STAIN Gajah Putih Takengon dengan harapan temuan dari penelitian ini akan mampu memberi masukan kepada para pendididik dalam memilih teknologi sebagai media dalam proses pengajaran dan pembelajaran, yang pada akhirnya diharapkan sumber daya manusia lulusan STAIN Gajah Putih Takengon dapat menjadi lulusan yang mumpuni.

\section{Tinjauan Pustaka}

\section{Internet}

Gerbang digital yang semakin canggih menuntut adanya juga penyeimbangan terhadap informasi keterbukaan, persoalan ini telah mendorong dilakukannya serangkaian penyesuaian serta keterbukaan kelambagaan serta tatanannya dalam orientasi tata nilai serta aspek pendukungnya. Seperti proses belajar dan mengajar dalam dunia pendidikan yang ada sekarang bisa dikawinkan dengan tehnologi terbarukan yang ada. Keberadaan internet saat ini tidak bisa ditampikkan dalam pengembangan proses belajar mengajar, internet sekarang merambah pada semua alat tehnologi dalam membantu manusia dengan penggunaan sistem secara online. Internet menurut (Drew Herwood, 1996) lahir pada akhir dekade 60-an saat United State Department of Defense (DoD) memerlukan standar baru untuk komunikasi Internetworking, yaitu standar yang mampu menghubungkan segala jenis komputer di DoD dengan komputer milik kontraktor militer, organisasi penelitian dan ilmiah di universitas. Belakangan ini diwilayah Indonesia sendiri hamper sampai pelosok negeri sudah dijangkau internet, ada 144 juta pengguna internet dan ini di pastikan merupakan terbanyak ketiga di dunia. Bahkan dilihat data dari (www.internetworldstats.com) dalam satu dasawarsa terakhir jumlah pengguna internet di dunia meningkat secara drastis, dari $0.4 \%$ pengguna dari seluruh penduduk dunia, naik hampir 60 kali lipat di tahun 2008, pada tahun 2000 pertumbuhan pengguna internet dunia naik rata-rata $2 \%$ dari total populasi dunia. Data di tahun 2008 menunjukkan pengguna internet di dunia mencapai $1,565,000,000$ pengguna atau $23.3 \%$ dari jumlah penduduk dunia. 
Internet yang menyentuh kehidupan masyarakat sekarang berdampak langsung terhadap aktifitas keseharian, kemudahan-kemudahan yang dibawanya seperti pemerolehan informasi yang dapat diakses dari gadget masing-masing. Potensi cara-cara manual dan Media konfensional akan ditinggalkan oleh masyarakat, kemajuan dan tantangan ini perlu di manfaatkan dari sisi positifnya sehingga ilmu pengetahuan dan tehnologi, lalu lintas informasi harus cepat, murah, efisien dan efektif.

\section{Website}

Berbicara tentang internet tidak akan lepas dengan pemahaman tentang world wide web. Web merupakan fungsi komunikasi cyber Bulletin Broad System (BBSs) yang dibantu jaringan internet, sehingga mampu untuk menjalankan fungsi e-mail, posting opini secara online, uploading dan downloading informasi dari satu komputer ke komputer atau satu gawai ke gawai lainnya (Rafaeli \& LaRose, 1993). Menurut (Yuhefizar, 2008) Web adalah suatu metode untuk menampilan informasi di internet, baik berupa teks, gambar, suara maupun video yang interaktif dan mempunyai kelebihan untuk menghubungkan (link) satu dokumen dengan dokumen lainnya (hypertext) yang dapat diakses melalui sebuah browser. Secara umum, Website atau World Wide Web dapat diartikan sebagai kumpulan halaman yang menampilkan informasi data teks, data gambar diam atau gerak, data animasi, suara, video dan atau gabungan dari semuanya, baik yang bersifat statis maupun dinamis yang membentuk satu rangkaian bangunan yang saling terkait dimana masing-masing dihubungkan dengan jaringan-jaringan halaman (hyperlink) (http://raghibnuruddin217.blogspot.com).

Lebih lanjut keberradaan web secara umum memiliki fungsi sebagai (1) Fungsi komunikasi, (2) Fungsi informasi, (3) Fungsi entertainment, (4) Fungsi transaksi. Selain itu ada beberapa jenis web yang dikelompokkan berdasarkan tujuannya, diantaranya yaitu: (1) Alat Pemasaran, (2) Nilai Tambah, (3) Katalog (4) E-Commerce, (5) ELearning, (6) Komunitas, (7) Portal, (8) Personal. (http://raghibnuruddin217.blogspot.com).

\section{Mesin Pencari (Search Engine)}

Program lain yang tidak dapat lepas dari sejarah kelahiran internet adalah search engine yang merupakan pengembangan dari website, mesin pencari menjadi salah satu bagian hal terpenting dari fasilitas internet yang berfungsi untuk menyimpan site atau segala jenis informasi dalam web. Mesin-mesin pencari ini memudahkan pengguna internet dalam mencari informasi, dengan mengetik kata yang kita cari maka mesin "pencari" akan bekerja. Mesin pencari yang dominan digunakan bahkan memonopoli internet pada saat ini seperti: Google, Yahoo!, MSN dan AOL (Statista, 2019).

\section{Weblog}

Weblog atau yang sering disebut blog tidak pernah lepas dari sejarah perkembangan internet. Orang yang pertama melakukan blogging adalah Justin Hall dengan internet-based journalist yang ia beri nama Justin's Links from The Underground pada tahun 1994. Pada saat itu istilah blogging belum diungkapkan, baru pada tanggal 17 Desember 1997 Jorn Barger menggunakan istilah weblog untuk menyebut website pribadi yang selalu di update secara berkala dan berisi link-link yang tersambung dengan website lain yang dianggap menarik, dan diisi dengan komentar-komentar mereka sendiri (Rosenberg, 2010). Perkembangan weblog selanjutnya banyak menghadirkan fasilitas yang lebih canggih dan cukup membantu penggunanya dalam mengekspresikan fungsi 
dan tujuan masing-masing dalam membuat blog. Walaupun weblog sebenarnya tidak bisa memuat data sebesar website.

\section{Social Media}

Berbicara tentang perkembangan internet juga tidak akan lengkap tanpa membicarakan tentang kemunculan fenomena social media yang menjadi aplikasi yang paling digemari di sepanjang sejarah keberadaan internet. Sebut saja friendster, facebook, myspace, twitter. Munculnya media sosial di atas sebenarnya menjadi tonggak perubahan nama menjadi web 2.0. Selain situs jejaring sosial, situs lain yang juga menandai lahirnya web 2.0 adalah wikipedia. Belakangan jejaring social ini merupakan aplikasi wajib pada gawai masyarakat sekarang seperti, Youtube video editor, Wevideo.com, Twitter.com, Facebook.com, Plus.google.com, Linkedin.com, Skype.com, Instagram.com, Telegram.com, Line, Whatsup ,Wechat, dan lainya minimal lima dari aplikasi tersebut terinstal pada gawai mayarakat sekarang ini (Statista, 2019).

\section{Metode Penelitian}

Penelitian ini menggunakan pendekatan diskriptif kuantitatif dengan Sampel dalam penelitian ini diambil dari 231 mahasiswa Multimedia STAIN Gajah Putih Takengon yang terdiri dari 130 mahasiswa laki-laki dan 101 orang mahasiswa perempuan. Instrument yang digunakan adalah kuesioner dalam bentuk skala likert berskala lima (1.Tidak pernah, 2. Jarang, 3. kadang-kadang, 4. kerap, 5. selalu). Seluruh responden yang diambil memiliki ala-alat digital otomatis seperti komputer, laptop, telepon genggam, PDA, iPod, MP3 atau MP4.

\section{Hasil dan Pembahasan}

Dari temuan penelitian yang diperoleh ditemukan bahwa para mahasiswa sering menggunakan internet sebagai alat untuk komunikasi sosial, mencari berita dan informasi, sebagai hiburan dan permainan serta sebagai multimedia yang ditampilkan dalam bentuk Tabel untuk mengetahui skor min, median dan standart deviasinya.

\section{a. Komunikasi sosial}

\begin{tabular}{lrrrrrrr}
\hline & \multicolumn{3}{c}{ Non- Mobile Digital Divices } & \multicolumn{3}{c}{ Mobil Devise } \\
\cline { 2 - 8 } Mean & \multicolumn{1}{c}{ IM } & MMS & VSM & Logon 25/7 & SMS & MMS & VMS \\
Standard Error & 4.393 & 2.470 & 2.135 & 4.268 & 4.258 & 2.297 & 1.659 \\
Median & 0.063 & 0.090 & 0.079 & 0.071 & 0.072 & 0.080 & 0.069 \\
Mode & 5 & 2 & 2 & 2 & 5 & 2 & 1 \\
Standar Deviasi & 0.957 & 1.369 & 1.195 & 1.195 & 1.088 & 1.217 & 1.038 \\
\hline
\end{tabular}

Dari distribusi tabel diatas dapat disimpulkan penggunaan internet oleh para mahasiswa mayoritas dalam penggunaan instan pesan (IM) dan SMS, hanya sebagian saja dari para mahasiswa yang sering menggunakan pesan multimedia (MMS) dan sedikit yang menggunakan VSM (Video messaging).

\section{b. Informasi dan berita}

Temuan penelitian menunjukkan bahwa jumlah terbesar penggunaan alat digital untuk mencari informasi dan berita ini frekuensi terbesar adalah terhadap hobi dan 
hiburan. Mahasiswa juga menggunakan internet untuk kebutuhan pembelajaran seperti mencari informasi dan pengetahuan seperti mengakses online portal, Learning Management System (LMS) atau bahan pembelajaran untuk pembelajaran elektronik seperti video tutorial atau E-book. Para mahasiswa juga sering mencari referensi dari kamus elektronik, ensiklopedi dan wiki pedia. Namun kadang-kadang mereka mencari informasi umum seperti berita dan melihat peristiwa yang terjadi. Temuan ini dapat dibuktikan dengan Tabel dibawah ini:

\begin{tabular}{|c|c|c|c|c|c|c|c|c|}
\hline & \multicolumn{4}{|c|}{ Non- Mobile Digital Divices } & \multicolumn{3}{|c|}{ Mobil Devise } & \multirow[b]{2}{*}{ 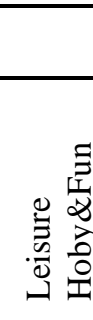 } \\
\hline & 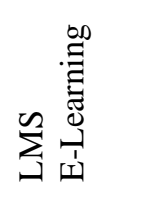 & 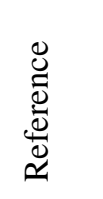 & 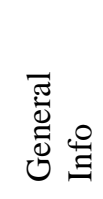 & 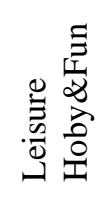 & 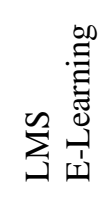 & $\begin{array}{l}\mathscr{U} \\
\tilde{0} \\
\stackrel{0}{0} \\
\simeq \\
\simeq\end{array}$ & 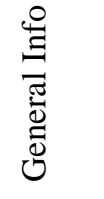 & \\
\hline Mean & 3.274 & 3.983 & 3.416 & 4.117 & 1.468 & 1.554 & 1.820 & 2.179 \\
\hline $\begin{array}{l}\text { Standard } \\
\text { Error }\end{array}$ & 0.075 & 0.068 & 0.075 & 0.068 & 0.063 & 0.069 & 0.074 & 0.094 \\
\hline Median & 3 & 4 & 3 & 4 & 1 & 1 & 1 & 2 \\
\hline Mode & 3 & 5 & 3 & 5 & 1 & 1 & 1 & 1 \\
\hline $\begin{array}{l}\text { Standar } \\
\text { Deviasi }\end{array}$ & 1.140 & 1.038 & 1.138 & 1.030 & 0.945 & 1.031 & 1.099 & 1.400 \\
\hline
\end{tabular}

\section{c. Jaringan sosial}

\begin{tabular}{|c|c|c|c|c|c|c|c|c|}
\hline & 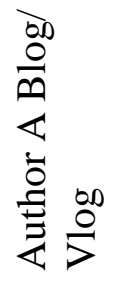 & 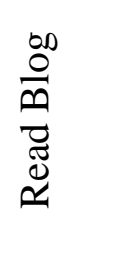 & $\begin{array}{l}\overline{\tilde{z}} \\
\tilde{\Xi} \\
\overline{0} \\
0\end{array}$ & ลิ & 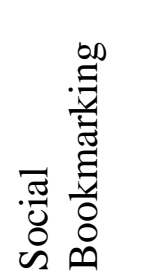 & $\stackrel{0}{0}$ & 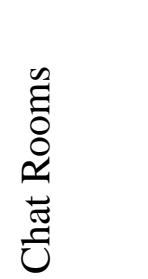 & $\begin{array}{l}\Xi \\
\Xi \\
0 \\
0 \\
0 \\
0 \\
0 \\
3\end{array}$ \\
\hline Mean & 3.089 & 3.425 & 2.098 & 4.026 & 2.004 & 3.203 & 2.916 & 3.251 \\
\hline Standard Error & 0.086 & 0.079 & 0.092 & 0.081 & 0.079 & 0.092 & 0.096 & 0.091 \\
\hline Median & 3 & 3 & 2 & 4 & 2 & 3 & 3 & 3 \\
\hline Mode & 3 & 3 & 1 & 5 & 1 & 5 & 3 & 5 \\
\hline $\begin{array}{l}\text { Standar } \\
\text { Deviasi }\end{array}$ & 1.296 & 1.195 & 1.246 & 1.223 & 1.194 & 1.380 & 1.441 & 1.374 \\
\hline
\end{tabular}

Temuan dalam penelitian ini menunjukkan para mahasiswa kadang-kadang membaca atau sebagai penulis blog. Para mahasiswa memiliki berbagai jaringan sosial seperti facebook, BBM, LINE, Instagram dan Whatsup untuk berinteraksi dan saling berbagi informasi baik itu untuk kepentingan pembelajaran maupun hiburan. Peer-to-peer (P2P) yang merupakan program untuk berbagi dan download informasi juga sering digunkan antar sesama mahasiswa kampus. Dari tabel diatas dapat disimpulkan bahwa penggunaan $\mathrm{P} 2 \mathrm{P}$ mencapai persentase terbesar dengan nilai min 4.026. Sedangkan frekuensi terendah berada pada penggunaan chatroom pada yahoo messanger. 
Jurnal As-Salam Vol. 3 No. 2 Mei - Agustus 2019: 18 - 28

Rahmanita Zakaria

\section{d. Permainan dan Hiburan}

\begin{tabular}{|c|c|c|c|c|c|c|}
\hline 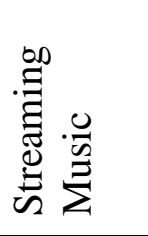 & 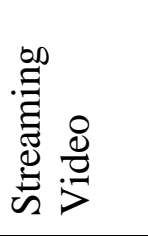 & 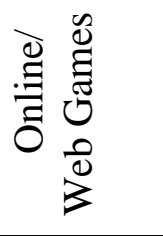 & 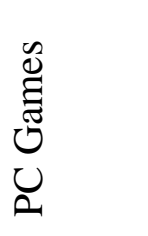 & 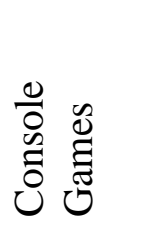 & 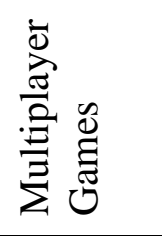 & 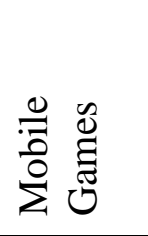 \\
\hline 4.556 & 4.257 & 3.665 & 3.789 & 2.846 & 3.211 & 2.638 \\
\hline 0.05 & 0.06 & 0.08 & 0.08 & 0.09 & 0.10 & 0.08 \\
\hline 0 & 2 & 4 & 4 & 9 & 6 & 7 \\
\hline 5 & 5 & 4 & 4 & 3 & 3 & 3 \\
\hline 5 & 5 & 5 & 5 & 1 & 5 & 1 \\
\hline 0.755 & 0.931 & 1.263 & 1.269 & 1.490 & 1.596 & 1.305 \\
\hline
\end{tabular}

Dari segi hiburan dan permainan dapat dilihat dari distribusi tabel diatas dapat dilihat hasil penelitian menunjukkan frekuensi terbesar mahasiswa menggunakan internet untuk kepentingan hiburan dan permainan dalam aliran musik (iTunes, streaming mp3, video musik, youtube dan lainnya) serta aliran video (film dan trailer). Sebagai generasi internet mereka juga tidak lepas dari permainan berbasis internet baik itu game online maupun melaui aplikasi yang sengaja didownload. Ada juga yang memanfaatkan telepon seluler tapi hanya sebagian kecil dari mereka.

\section{e. Multimedia}

\begin{tabular}{|c|c|c|c|c|c|}
\hline & 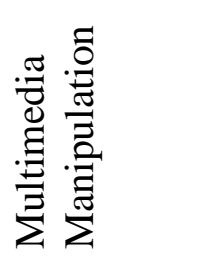 & 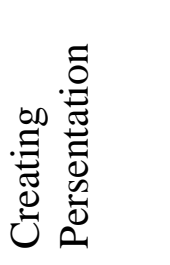 & 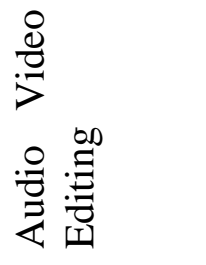 & 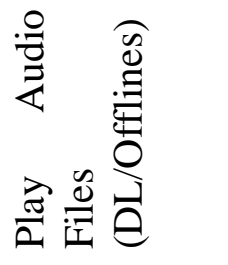 & 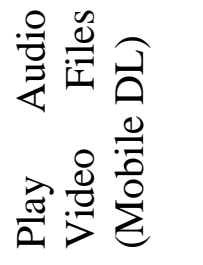 \\
\hline Mean & 4.556 & 4.257 & 3.665 & 3.789 & 2.846 \\
\hline Standard & 0.050 & 0.062 & 0.084 & 0.084 & 0.099 \\
\hline $\begin{array}{l}\text { Error } \\
\text { Median }\end{array}$ & 5 & 5 & 4 & 4 & 3 \\
\hline Mode & 5 & 5 & 5 & 5 & 1 \\
\hline $\begin{array}{l}\text { Standar } \\
\text { Deviasi }\end{array}$ & 0.755 & 0.931 & 1.263 & 1.269 & 1.490 \\
\hline
\end{tabular}

Tabel diatas menunjukkan penggunaan internet untuk menciptakan memanipulasi multimedia. Frekuensi terbesar menunjukkan bahwa para mahasiswa sering menggunakan internet untuk mengedit foto atau gambar, kadang-kadang untuk mengedit membuat slide show untuk kebutuhan presentasi baik itu power point maupun persentasi berbasis html. Sebagai generasi internet menciptakan suatu permainan merupakan pekerjaan yang serius (Prensky, 2001). Para mahasiswa juga banyak menghabiskan waktu mereka untuk mendownload music atau video digital dan hanya sedikit mahasiswa yang menggunakan telepon seluler untuk mendownload. 


\section{Implikasi Terhadap Pendidikan}

Tenaga Pengajar dapat memanfaatkan kebiasaan para mahasiswa dalam menggunakan internet yang senantiasa mereka gunakan sebagai hiburan menjadi salah satu alat dan metode pembelajaran baru yang disesuaikan dengan kurikulum untuk menciptakan pembelajaran yang lebih efektif. Pertama, pengajar dapat mengadopsi teknik permainan sebagai salah satu pendekatan dalam menciptakan pembelajaran yang lebih efektif melalui kurikulum yang ditawarkan. Ini disesuaikan dengan teori-teori pendidikan seperti behaviorisme, konstruktivisme, dan teori pendididkan lainnya (Prensky, 2001; Van Eck, 2006). Mengemukakan bahwa melalui permainan dengan menerapkan sistem pembelajaran kolaboratif dan kooperatif sesama mahasiswa diluar kelas dengan merancang pembelajaran secara maksimal dan membawa mahasiswa pada kenyataan riil untuk menciptakan pembelajaran yang aktif. Ketiga, pembelajaran kolaboratif dan kooperatif sesama mahasiswa diluar kelas dapat menciptakan pembelajaran yang aktif. Pengajar dapat memanfaatkan teknologi IM sebagai salah satu alat dalam melakukan pembelajaran secara informal dan lebih santai.

\section{Hasil Penelitian}

Dari hasil studi yang dilakukan ditemukan bahwa mahasiswa menggunakan internet untuk kebutuhan Interaksi sosial, mencari informasi dan berita, sebagai jaringan sosial, sarana untuk mencari hiburan dan permainan, sebagai multimedia. Para mahasiswa sering menghabiskan waktu untuk interaksi sosial dengan menggunakan Instan Massage (IM), Multimedia Massage (MMS), dan Video massaging (VSM). Hal ini dapat dilihat dari temuan penelitian yang menunjukkan 3.62 persen aktif dan 19,9 persen sering aktif dalam durasi 24 jam baik itu dengan menggunakan komputer atau telepon seluler. Kecenderungan alat interaksi yang digunakan adalah penggunakan Instan massage seperti Yahoo dan MSN massager. Saya sangat setuju dengan temuan studi ini melihat dengan fakta-fakta yang terjadi dilingkungan sekitar apalagi dikalangan pelajar yang memiliki internet otomatis seperti laptop, PC ataupun telepon seluler yang sering kali digunakan sebagai alat untuk berkomunikasi. Banyak para mahasiswa yang menghabiskan waktu mereka untuk chating melalui instant pesan atau telepon seluler yang tidak disadari akan menghabiskan waktu mereka.

Untuk kebutuhan informasi dan berita, temuan menunjukkan bahwa para mahasiswa menggunakan internet dalam keseharian mereka untuk mencari informasi dan pengetahuan dengan cara mengakses online portals, pembelajaran dengan menggunakan management system (LMS), dan e-pembelajaran berupa video, tutorial, atau e -book. Dan banyak juga para mahasiswa yang menggunakan internet sebagai pengisi waktu kosong, hal ini dilakukan hanya sekedar hobi dan mencari kesenangan saja. Para mahasiswa juga sering menggunakan alat digital untuk mencari referensi dari kamus elektronik dan mencari berita terbaru melalui wiki pedia. Akan tetapi sering penggunaan internet dalam kebutuhan sehari-hari hanya untuk informasi-informasi umum yang terkait dengan berita atau kejadian-kejadian yang terkini.

Disamping itu temuan penelitian untuk penggunaan alat digital untuk jaringan sosial biasanya merupakan cara berinteraksi berbasis teknologi web yang didesain untuk memfasilitasi kerjasama dan saling berbagi sesama pengguna. Mahasiswa biasanya mempuanyai berbagai jaringan sosial seperti blog, BBM, Facebook, LINE, Instagram dan Whatsup yang digunakan sebagai media untuk berkomunikasi dan saling berbagi info. Disamping itu para mahasiswa juga sering menggunakan Peer to peer (P2) yang merupakan program untuk saling berbagi dan mendownload file dan MMU yang dikenal 
dengan cybertraker dalam dunia intranet. Data-data yang dibagi biasanya berupa materi pembelajaran, hiburan baik itu dalam bentuk video, music dan permainan. Fasilitas lainnya yang sering digunakan para mahasiswa untuk berkomunikasi dengan keluarga dan kerabat yang berada jauh dari lingkungan adalah yahoo! voice chat.

Karena hal ini dapat memfasilitasi proses berinteraksi secara langsung dengan dapat melihat sendiri tampilan gambar dan mendengar langsung suara orang yang kita ajak berkomunikasi. Selain itu para mahasiswa juga sering mengunjungi chat room dan forum diskusi untuk bersosialisasi berbasis web. Selanjutnya dari temuan penelitian terhadap penggunaan internet untuk kebutuhan hiburan dan permainan menunjukkan bahwa frekuensi terbesar adalah untuk hiburan. Para mahasiswa menggunakan alat digital untuk kebutuhan musik dan video. Sebagai generasi internet para mahasiswa juga biasanya sering menggunakan permainan berbasis web baik itu secara online, permainan komputer, konsol game, permainan ganda ataupun permainan yang ada ditelepon seluler. Sedangkan sebagai alat multimedia para mahasiswa terampil dalam bekerja dengan menggunakan aplikasi yang ada dalam multimedia.

Biasanya para mahasiswa menggunakannya untuk memanipulasi foto atau gambar, membuat power point, persentasi berbasis html dan mengedit video atau suara. Menurut penelitian prensky para mahasiswa juga menghabiskan banyak waktu mereka dengan menggunakan internet untuk mendownload musik digital atau video (Prensky' 2001). Ulasan ini juga menunjukkan bahwa sedikit sekali yang menggunakan telepon seluler untuk kebutuhan ini. Pengembangan teknologi multimedia yang menekankan kepada unsur interaktif telah membawa persepsi baru dalam era penggunaan komputer dalam pendidikan. Ianya mulai mempertimbangkan teori-teori pembelajaran atau yang terkait dengannya berdasarkan suasana dan kebutuhan saat yang menekankan bagaimana mahasiswa belajar (Rasyad, 2013).

Dari hasil penelitian diatas dapat dilihat bahwa penelitian ini mengkaji tentang sejauh mana penggunaan internet di kalangan mahamahasiswa sarjana dalam era digital yang sedang terjadi saat ini. Kecanggihan internet yang terus berkembang pesat dan selalu membawapembaharuan dan inovasi baru dengan berbagai fasilitas yang ditawarkan sangat menarik minat para mahasiswa, khususnya para pelajar muda yang berada ditingkat universitas. Kecenderungan penggunaan internet ini biasanya karena kebutuhan mahasiswa yang saat ini menuntut mereka menggunakan digital sebagai salah satu alat dalam proses pengajaran dan pembelajaran yang saat ini lebih kecendung menggunakan fasilitas-fasilitas teknologi dan sistem yang modern untuk kebutuhan pembelajaran seperti penggunaan, komputer dan internet baik itu melalui system pembelajaran berbasis web seperti online portal, LMS, e-learning, video tutorial, e-book dan lainsebagainya. Namun demikian dari temuan penelitian diatas dapat kita lihat bahwa internet ini lebih banyak digunakan untuk kebutuhan hiburan baik itu berupa permainan, video, musik, ataupun social networking. Para mahasiswa lebih banyak menghabiskan waktu mereka untuk hiburan seperti menggunakan instan pesan baik itu melalui yahoo massanger, whats-up, facebook, LINE, twiter dan fasilitas jaringan sosial lainnya, serta hiburan lainnya seperti permainan dan musik baik itu melalui internet maupun ipod, MP3 dan MP4. Jadi dari penelitian diatas dapat disimpulkan bahwa para peajar lebih berfokus pada penggunaan internet sebagai hiburan dikalangan mahasiswa dibandingkan dengan memanfaatkan digital sebagai alat bantu dalam proses pengajaran dan pembelajaran bagi mereka.

Namun biasanya para mahasiswa menggunakan internet sebagai hiburan setara dengan mereka menggunakannya untuk kebutuhan pembelajaran, seperti menghidupkan musik pada saat mengerjakan tugas atau mengaktifkan instant masej pada saat mencari 
bahan pembelajaran. Jadi para mahasiswa membuat fasilitas-fasilitas digital sebagai hiburan saat mereka lelah atau kehabisan ide dalam mengerjakan tugas. Namun hal ini juga dapat berdampak buruk terhadap konsentrasi mahasiswa, mereka sering kali lebih disibukkan dengan hiburan-hiburan tersebut sehingga waktu untuk belajar jauh lebih sedikit dibandingkan dengan waktu yang terbuang sia-sia untuk hiburan tampa mereka sadari.

Penelitian ini juga hanya mengambil sampel para mahasiswa yang memiliki internet sendiri terutama komputer, laptop atau Android. Sedangkan jika proses pengajaran yang diusulkan agar memanfaatkan atau membuat kebiasaan penggunaan fasilitas yang ada dalam internet sebagai salah satu cara untuk membuat pembelajara lebih efektif dan bervariasi yang di sesuaikan dengan kurikulum yang benar, maka secara langsung akan melibatkan seluruh mahasiswa dan dapat kita ketahui bahwa tidak keseluruhan dari para mahasiswa-mahasiswa STAIN Gajah Putih Takengon memiliki komputer, laptop android sendiri. Sehingga seharusnya kita juga perlu mengkaji kecenderungan penggunaan digital dikalangan mahasiswa yang tidak memiliki fassilitas digital sendiri. Baik itu yang menggunakan laboratorium atau pun Warnet untuk memenuhi kebutuhan mereka.

Meskipun teknologi digital mampu memperkuat dan merubah lingkungan pembelajaran dengan memungkinkan pembelajaran berlangsung kapan saja dan dimana saja. Akan tetapi tidak semua mahasiswa STAIN Gajah Putih Takengon siap dengan penemuan yang telah dikemukakan diatas. Ini karena penggunaan alat-alat dan teknologi ini membutuhkan biaya yang cukup mahal. Jadi pembelajaran yang dimaksudkan disini bukan sebagai aktifitas utama dalam pembelajaran melainkan hanya sekedar pendukung lainnya dalam menciptakan pembelajaran yang efektif.

\section{Implikasi Terhadap Pendidikan}

Dalam implikasinya terhadap pendidikan integrasi teknologi yang didirikan dan implementasi dari teknologi baru untuk pembelajaran bisa berbasis diacadangkan dari kebiasaan digital para mahasiswa. Dari penelitian yang dilakukan ini diperoleh bahwa terdapat beberapa implikasi terhadap lingkungan mahasiswa seperti dijelaskan dibawah ini: Pertama, melihat banyaknya kecenderungan penggunaan internet oleh para mahasiswa terutama untuk kebutuhan hiburan dan permainan pengajar dapat mengadopsi teknik pembelajaran yang membuat permainan sebagai salah satu pendekatan untuk pembelajaran melalui kurikulum yang ditawarkan sebagai salah satu bahan pembelajaran yang efektif, umpan balik, behaviorisme, konstraktivisme, dan teori serta teori pendidikan lainnya (Prensky, 2001; Van Eck, 2006), penelitian sebelumnya juga menemukan bahwa melalui berbagai permainan sosialisasi terhadap keterampilan juga dapat ditingkatkan. Kedua, Neo, 2003 mengemukakan bahwa melalui permainan dengan menerapkan sistem pembelajaran kolaboratif dan kooperatif sesama mahasiswa diluar kelas dengan merancang pembelajaran secara maksimal dan membawa mahasiswa pada kenyataan riil untuk menciptakan pembelajaran yang aktif. Yang ketiga adalah pengajar dapat memanfaatkan teknologi IM yang biasa digunakan mahasiswa dalam kesehariannya sebagai alat komunikasi dalam ruang kelas dengan lebih untuk meningkatkan dalam kelas seperti konsultasi, berhubungan langsung dengan tenaga pengajar, mengirim pesan langsung kepada rekan-rekan, dan saling berbagi informasi, sehingga pembelajaran dapat berlangsung secara informal dan lebih santai.

Sebagai seorang pengajar kita harus senantiasa mampu menyesuaikan system dan pendekatan dalam mengajar dengan lingkungan dimana kita mengajar. Hal ini senada dengan pendapat Judy lever et al (2003) yang menyatakan bahwa penggunaan berbagai 
system pendekatan dalam pengajaran dan pembelajaran memberikan kita cara untuk melihat diri kita sendiri, lingkungan tempat kita mengajar, yang mencerminkan kita adalah seorang pengajar yang berada dalam suatu system. Internet yang terkandung dalam teknologi saat ini juga member berbagai fasilitas kepada dalam proses pengajaran dan pembelajaran sehingga pembelajaran dapat berlangsung dimana saja dan kapan saja. Sehingga pembelajaran tidak lagi terhambat karena keterbatasan jarak, seperti dalam proses pembelajaran jarak jauh yang saat ini sudah mulai berkembang pesat diberbagai universitas. Hal ini secara otomatis akan mengzimatkan waktu dan biaya produksi karena para mahasiswa tidak lagi harus menghabiskan waktu yang banyak dan mengeluarkan biaya yang tinggi hanya untuk menjelajahi perpustakaan-perpustakaan yang ada diseluruh dunia untuk mencari bahan pembelajaran.

Selain itu juga dapat memudahkan para mahasiswa dalam melakukan proses pembelajaran, dengan mengganti buku teks yang semesti harus banyak dibawa hanya dengan notebook saja karena mahasiswa dapat membaca buku dalam bentuk softcopy atau sofware. Biaya untuk mendapatkan informasi dalam bentuk digital sangat murah dibandingkan dengan dalam bentuk hard copy. Pencarian informasipun dapat dilakukan dengan cepat sesuai dengan yang dinginkan Sumber yang diperoleh pun akan selalu up to date tampa harus membeli buku secara berulang-ulang. Penggunaan multimedia dalam bidang pendididkan juga memungkinkan informasi dalam jumlah yang besar yang disalurkan untuk kebutuhan mahasiswa. Informasi tersebut pula dapat dicapai berdasarkan penetapan waktu dan tempat mahasiswa itu sendiri. Multimedia juga dikatakan mampu menjadi media komunikasi yang positif dan efektif karena melalui teks, audio, video serta animasi yang beragam warna dan corak mampu ditampilkan dalam sebuah layar pada satu waktu yang sama. Disamping itu penggunaan media interaktif juga ternyata mampu menarik perhatian serta mudah untuk dipahami dibandingkan penggunaan bahan-bahan yang statis dan bisu. Pengguna yang merasa tertarik akan member lebih konsentrasi pada tampilan isi konten atau informasi yang ingin disampaikan dan berikutnya ini akan memungkinkan proses pengiriman yang lebih efisien. Semuanya ini menguatkan lagi secara rasional pernyataan bahwa multimedia sangat cocok digunakan dalam proses pengajaran dan pembelajaran.

\section{Kesimpulan}

Dari hasil penelitian yang dilakukan dapat disimpulkan bahwa konsumsi internet yang dilakukan oleh Mahasiswa STAIN Gajah Putih Takengon sangat aktif, mahasiswa menggunakan internet sebagai alat komunikasi, jaringan sosial, mencari informasi, penggunaan multimedia, juga sebagai alat untuk mencari hiburan dan permainan lainnya. Hampir keseluruhan dari mereka adalah pengguna internet dalam skala yang besar untuk kebutuhan menikmati permainan dan hiburan yang ada dalam era digital sekarang ini. Mereka selalu menggunakan instan pesan sebagai sarana hiburan dan hamper rata-rata selalu online dalam durasi 24 jam. Generasi internet STAIN Gajah Putih Takengon bukan juga penggemar teknologi web 2.0, oleh karena itu dosen sebaiknya melanjutkan penggunaan teknologi dalam pengajaran yang didirikan untuk menciptakan variasi dan gaya pembelajaran terbaru yang komplek bagi mahasiswa untuk lebih menarik minat para mahasiswa dan menambah keefektifan serta efektivitas proses pengajaran dan pembelajaran. Meskipun belum jelas apakah teknologi yang berkembang saat ini akan meresap dalam waktu dekat, seperti temuan yang di peroleh kenedi dkk, pada tahun 2007 yang menyatakan bahwa temuan ini merupakan hasil dari pemahaman terhadap generasi internet dapat menginformasikan perbaikan-perbaikan dalam teknologi saat ini yang 
berbasis pada kegiatan belajar-mengajar, serta membawa ke arah pengembangan teknologi pendidikan yang lebih cerah dimasa yang akan datang.

\section{Daftar Pustaka}

Azhar, Rasyad. 2013. Media Pembelajaran Edisi Revisi Cetakan Ke-16. Jakarta: Raja Grafindo.

Drew Heywood (1996). Networking with Microsoft TCP/IP. Indianapolis, USA: New Riders Publishing.

Internet World Stats. Usage and Population Statistics. (2018) Retrieved from https://www.internetworldstats.com/ Diakses tanggal 11-05-2018.

Judy Lever et al. 2003. Teaching and Learning with Technology. London: Pearson.

Kietzmann, Jan H. (2011). "Social media? Get serious! Understanding the functional building blocks of social media". Business Horizons. 54 (3): 241251. doi:10.1016/j.bushor.2011.01.005. ISSN 0007-6813. Diakses tanggal 11-122018.

Prensky, Marc. 2001. "Digital Natives, Digital Immigrants." On the Horizon 9(5): 1-6. doi:10.1108/10748120110424816. Retrieved from http://marcprenskyarchive.com/writings/ Diakses tanggal 11-05-2018.

2001. From Digital Natives to Digital Wisdom: Hopeful Essays for 21st Century Learning. Retrieved from http://marcprenskyarchive.com/writings/ Diakses tanggal 11-05-2018.

2001. Digital game-based learning. New York: McGraw-Hill.

2006. Education to Better Their World: Unleashing the Power of 21st Century Kids. USA: Columbia TC Press.

2008. The emerging alternative to our current world-wide academic education: REAL-WORLD-PROJECT / EMPOWERMENT EDUCATION. Retrieved from https://bit.ly/2MLKqFq] Diakses tanggal 11-05-2018.

Rafaeli, S., \& LaRose, R. (1993). Electronic bulletin boards and 'public goods' explanation of collaborative mass media. Communication Research, 20 (2), 277 297.

https://www.researchgate.net/publication/249682940_Electronic_Bulletin_Boards_ and_'Public_Goods'_Explanations_of_Collective_Mass_Media

Raghibnuruddin. 2013. Pengertian \& definisi WEB. Retrieved from http://raghibnuruddin217.blogspot.com Diakses 05 Oktober 2019.

Rosenberg, Scott. 2010. Say Everything: How Blogging Began, What It's Becoming, and Why It Matters Paperback. USA: Broadway Books.

Sharon E Smaldino, et al. 2011. Instructional Technology and Media for Learning. Jakarta: Kencana.

Statista. 2019. Most famous social network sites 2019, by active users. Retrieved from https://www.statista.com/statistics/272014/global-social-networks-ranked-bynumber-of-users/ Diakses tanggal 23-06-2019.

Yuhefizar, 2008. 10 Jam Menguasai Internet, Teknologi dan Aplikasinya. Jakarta: Elex Media Komputindo.

Van Eck, 2006. Digital Game Based LEARNING It's Not Just the Digital Natives Who Are Restless. Retrieved from https://www.researchgate.net/publication/242513283_Digital_Game_Based_LEAR NING_It's_Not_Just_the_Digital_Natives_Who_Are_Restless Diakses tanggal 1105-2018. 